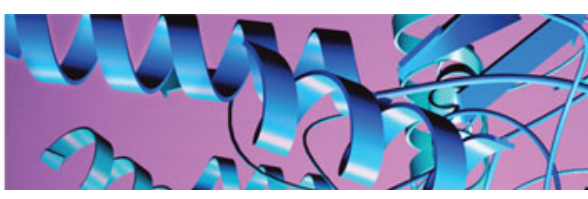

\title{
Electron flow through biological molecules: does hole hopping protect proteins from oxidative damage?
}

\author{
Jay R. Winkler and Harry B. Gray* \\ Beckman Institute, California Institute of Technology, Pasadena, CA 91125, USA \\ Quarterly Reviews of Biophysics (2015), 48(4), pages 411-420 doi:10.1017/S0033583515000062
}

Abstract. Biological electron transfers often occur between metal-containing cofactors that are separated by very large molecular distances. Employing photosensitizer-modified iron and copper proteins, we have shown that single-step electron tunneling can occur on nanosecond to microsecond timescales at distances between 15 and $20 \AA$. We also have shown that charge transport can occur over even longer distances by hole hopping (multistep tunneling) through intervening tyrosines and tryptophans. In this perspective, we advance the hypothesis that such hole hopping through Tyr/Trp chains could protect oxygenase, dioxygenase, and peroxidase enzymes from oxidative damage. In support of this view, by examining the structures of P450 (CYP102A) and 2OG-Fe (TauD) enzymes, we have identified candidate Tyr/Trp chains that could transfer holes from uncoupled high-potential intermediates to reductants in contact with protein surface sites.

Key words: electron transfer, protein radical, hole hopping, azurin, cytochrome P450.

\section{Background}

Many vital biological transformations involve the incorporation of one (monooxygenases) or two (dioxygenases) O-atoms from molecular oxygen into organic substrates. Enzymes that utilize oxygen must coordinate the delivery of four protons and four electrons to $\mathrm{O}_{2}$ in order to prevent the formation of harmful molecular oxidants $\left(\mathrm{O}_{2}^{-}, \mathrm{HO}_{2}^{-} \mathrm{H}_{2} \mathrm{O}_{2}\right.$, and $\mathrm{HO}^{\circ}$ ), collectively known as reactive oxygen species (ROS). It is our view that the risks posed by reactive intermediates are so great that oxygen-utilizing enzymes have protection mechanisms to help them avoid inactivation when the primary electron/proton transfer mechanism is disrupted.

The mechanism of $\mathrm{O}_{2}$ reduction by cytochrome $c$ oxidase illustrates some of the challenges facing these enzymes (Wikström, 2012; Yu et al. 2011, 2012). Reaction of the fully four-electron reduced enzyme $\left(\mathrm{Cu}_{\mathrm{A}}^{\mathrm{II}, \mathrm{I}}, \mathrm{Fe}^{\mathrm{II}}\right.$-heme $a$, $\mathrm{Fe}^{\mathrm{II}}$-heme $a_{3}$, and $\mathrm{Cu}_{\mathrm{B}}^{\mathrm{I}}$ ) with $\mathrm{O}_{2}$ generates an intermediate designated as $\mathrm{P}_{\mathrm{R}}$. When the two-electron reduced, mixed

\footnotetext{
* Author for correspondence: Beckman Institute, MC 139-74, California Institute of Technology, 1200 E. California Boulevard, Pasadena, CA 91125, USA. Tel: +626-395-6500; Fax: +626-449-4159; Email: hbgray@caltech.edu
}

valence enzyme $\left(\mathrm{Cu}_{\mathrm{A}}{ }^{\mathrm{II}, \mathrm{II}}, \mathrm{Fe}^{\mathrm{III}}\right.$-heme $a, \mathrm{Fe}^{\mathrm{II}}$-heme $a_{3}$, and $\mathrm{Cu}_{B}{ }^{\mathrm{I}}$ ) reacts with $\mathrm{O}_{2}$, the $\mathrm{P}_{M}$ intermediate is formed. The $\mathrm{O}-\mathrm{O}$ bond has been cleaved in both $\mathrm{P}_{\mathrm{R}}$ and $\mathrm{P}_{\mathrm{M}}$ to produce $\mathrm{Fe}^{\mathrm{IV}}(\mathrm{O})$-heme $a_{3}$ and $\mathrm{Cu}_{\mathrm{B}}{ }^{\mathrm{II}}$ in the binuclear site. The difference between $P_{R}$ and $P_{M}$ is in the source of the fourth electron: $\mathrm{P}_{\mathrm{M}}$ is thought to have a $\mathrm{Tyr}^{244}$ radical (bovine numbering), whereas the fourth electron in $\mathrm{P}_{\mathrm{R}}$ is provided by $\mathrm{Fe}^{\mathrm{II}}$-heme $a$. When $\mathrm{P}_{\mathrm{M}}$ is prepared using $\mathrm{H}_{2} \mathrm{O}_{2}$, the hole on $\left(\mathrm{TyrO}^{\bullet}\right)^{244}$ is believed to migrate through $\left(\operatorname{Trp}^{\cdot+}\right)^{236}$ to $(\mathrm{TyrO})^{-129}$; the latter residue is suggested to participate in proton pumping ( $\mathrm{Yu}$ et al. 2012). The key point is that $\mathrm{Tyr}^{244}$ is available to fill the gap when the fourth electron required for $\mathrm{O}_{2}$ reduction cannot be supplied by $\mathrm{Fe}^{\mathrm{II}}$-heme $a$ (Wikström, 2012; Yu et al. 2012).

In many oxygenases, including the cytochromes P450 (P450) and the 2-oxo-glutarate-dependent nonheme iron oxygenases (2OG-Fe), the four electrons required for $\mathrm{O}_{2}$ reduction have different origins (Fig. 1). Typically, two electrons are delivered from a reductase (P450) or co-substrate (2OG), and the remaining two electrons are provided by the organic substrate (Denisov et al. 2005; Hausinger, 2004; 


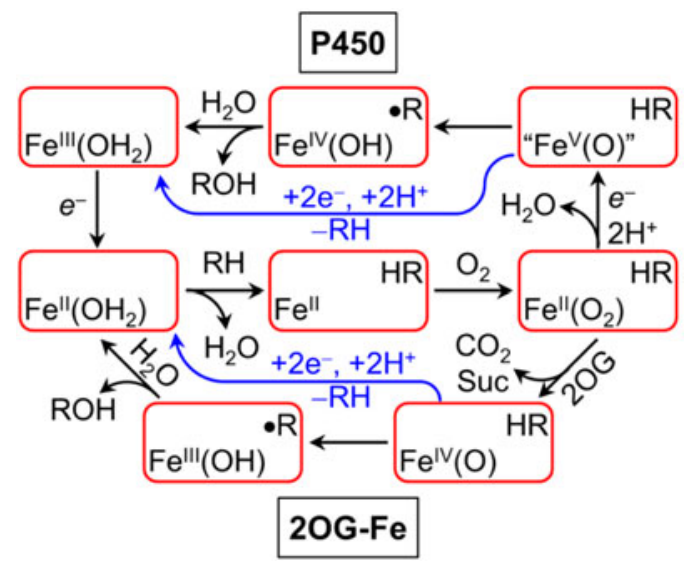

Fig. 1. Schematic representation of the catalytic mechanisms of P450 and 2OG-Fe oxygenases: RH, substrate; 2OG, 2-oxoglutarate; Suc, succinate. Black arrows indicate the functional substrate hydroxylation pathways. Blue arrows indicate oxidase uncoupling pathways.

Whitehouse et al. 2012). In the consensus mechanism for iron oxygenases, the first two electrons induce $\mathrm{O}-\mathrm{O}$ bond cleavage, producing a powerfully oxidizing ferryl species. The ferryl complex abstracts a hydrogen atom from the substrate and $\mathrm{HO}^{\circ}$ rebound leads to hydroxylated product (Denisov et al. 2005; Hausinger, 2004; Whitehouse et al. 2012). For enzymes with broad substrate specificities, or when operating in the presence of xenobiotic compounds, the fidelity of substrate oxidation is less than $100 \%$, with potentially damaging consequences (Chen et al. 2008; De Matteis et al. 2012; Denisov et al. 2007a; Grinkova et al. 2013; Saban et al. 2011; Staudt et al. 1974). This circumstance is manifested as an increased molar ratio of $\mathrm{O}_{2}$ consumption to substrate hydroxylation (uncoupling). We think it likely that organisms have evolved protection mechanisms to guard against deactivation of oxygenase enzymes in the event of uncoupled $\mathrm{O}_{2}$ consumption. In particular, we suggest that radical transfer pathways are employed to deliver strongly oxidizing holes ( $\mathrm{E}^{\circ} \sim 1 \mathrm{~V}$ versus $\mathrm{NHE}$ ) from ferryl complexes in active sites to less fragile regions of oxygenases.

In this perspective, we will advance the hypothesis that there are potentially protective radical chains in P450 and 2OG-Fe; but first we will review what we know about the factors controlling hopping through aromatic amino acids in multistep electron tunneling constructs designed in azurin, a prototypal cupredoxin.

\section{Radical transfer pathways in azurin}

Azurin is a robust cupredoxin (128 residues) that is amenable to site-directed mutagenesis and surface-labeling with photosensitizers (Farver \& Pecht, 2011; Gray \& Winkler, 2010; Reece \& Nocera, 2009; Wilson et al. 2013). Oxidized radicals of Trp and Tyr are substantially stronger acids than their neutral precursors $\left(\operatorname{Trp}, \mathrm{p} K_{\mathrm{a}}>14 ; \operatorname{Trp}^{\cdot+}, \mathrm{p} K_{\mathrm{a}}=4\right.$; TyrOH, $\mathrm{p} K_{\mathrm{a}}=10$; TyrOH $^{*+}, \mathrm{p} K_{\mathrm{a}}=-1$ ) (Aubert et al. 2000; Bonin et al. 2010; Costentin et al. 2009; Harriman, 1987; Jovanic et al. 1986); management of the acidic proton is a critically important factor controlling radical formation with these amino acids. Proton management is particularly challenging for buried amino acids and, thus far, we have not succeeded in detecting buried Trp or Tyr radicals as electron transfer (ET) intermediates. Our kinetics data indicate that surface exposed $\mathrm{Trp}^{\circ+}$ and $\mathrm{NO}_{2} \mathrm{TyrO}^{\circ}$ radicals can, in appropriate constructs, accelerate $\mathrm{Cu}^{\mathrm{I}}$ oxidation by distant Re- and Ru-diimine complexes (Shih et al. 2008; Warren et al. 2013a).

\section{Multistep ET through Trp and Tyr radicals in azurin}

We have used Pseudomonas aeruginosa azurin as a test bed for mechanistic investigations of Trp and Tyr radical formation in protein ET reactions (Blanco-Rodriguez et al. 2011; Shih et al. 2008; Takematsu et al. 2013; Warren et al. 2012, 2013a). Our initial investigation revealed that $\mathrm{Cu}^{\mathrm{I}}$ oxidation by a photoexcited $\mathrm{Re}^{\mathrm{I}}$-diimine complex $\left(\operatorname{Re}^{\mathrm{I}}(\mathrm{CO})_{3}\right.$ (4,7-dimethyl-1,10-phenanthroline)) covalently bound at $\mathrm{His}^{124}$ on a $\mathrm{His}^{124} \mathrm{Gly}^{123} \mathrm{Trp}^{122} \mathrm{Met}^{121} \beta$-strand (ReHis ${ }^{124} \mathrm{Trp}^{122} \mathrm{Cu}^{\mathrm{I}}$-azurin) occurs in a few nanoseconds, fully two orders of magnitude faster than documented for single-step electron tunneling at a $19-\AA \AA$ donor-acceptor distance, owing to a two-step hopping mechanism involving a $\operatorname{Trp}^{\bullet+}$ radical intermediate (Shih et al. 2008).

Our work on multistep ET in sensitizer-modified azurin is informed by semiclassical ET theory (Marcus \& Sutin, 1985). Given a particular spatial arrangement of redox cofactors, we can predict driving-force dependences of the relative time constants for single-step $\left(\tau_{\mathrm{ss}}=1 / k_{\mathrm{ss}}\right)$ and multistep ( $\left.\tau_{\text {hop }}\right)$ electron transport (Warren et al. 2012). Alternatively, given the redox and reorganization energetics, we can predict the hopping propensity for different cofactor arrangements (Warren et al. 2013a). We considered three $\mathrm{Ru}\left(2,2^{\prime} \text {-bipyridine }\right)_{2}($ imidazole $)\left(\mathrm{His}^{\mathrm{X}}\right)$-labeled azurins $\left(\right.$ RuHis $^{107}$, RuHis ${ }^{124}$, and RuHis ${ }^{126}$ ) and examined the hopping advantage $\left(\tau_{\mathrm{ss}} / \tau_{\mathrm{hop}}\right)$ for a protein with a generalized intermediate (Int) situated between a diimine- $\mathrm{Ru}^{\mathrm{III}}$ oxidant and $\mathrm{Cu}^{\mathrm{I}}$ (Warren et al. 2013a). In all cases, the greatest hopping advantage occurs in systems where the Int- $\mathrm{Ru}^{\mathrm{III}}$ distance is up to $5 \AA$ shorter than the Int- $\mathrm{Cu}^{\mathrm{I}}$ distance. The hopping advantage increases as systems orient nearer a linear Donor-Int-Acceptor configuration, owing to minimized intermediate tunneling distances. The smallest predicted hopping advantage is in RuHis ${ }^{124}$ azurin, which has the shortest $\mathrm{Ru}-\mathrm{Cu}$ distance of the three proteins. The hopping advantage is nearly lost as $\Delta G^{\circ}$ for the first step $\left(\mathrm{Ru}^{\mathrm{III}} \leftarrow\right.$ Int) rises above $+0.15 \mathrm{eV}$. Isoergic initial steps provide a wide distribution of arrangements, where advantages as great as $10^{4}$ are possible (for a fixed donor-acceptor distance of 23.7 or $25.4 \AA$ ). A slightly exergonic Int $\rightarrow \mathrm{Ru}^{\mathrm{III}}$ step 


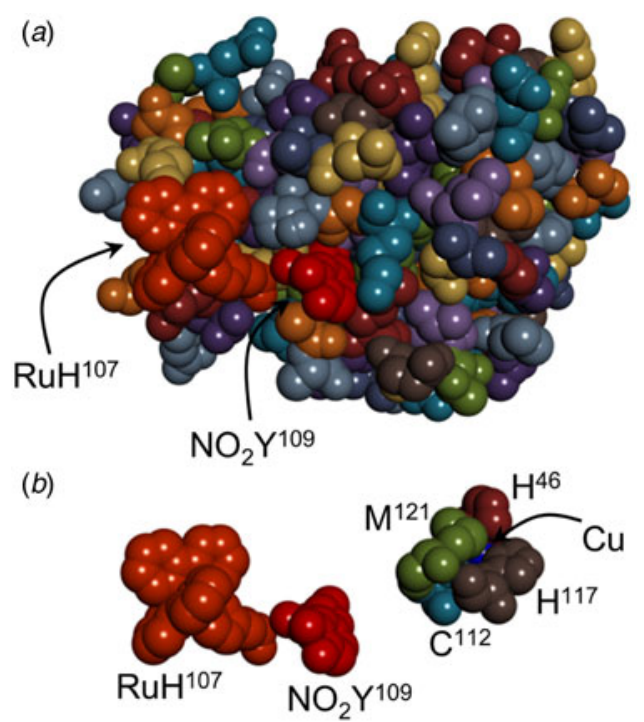

Fig. 2. (a) Space-filling structural model of $\mathrm{RuHis}^{107} \mathrm{NO}_{2} \mathrm{TyrOH}^{109} \mathrm{Cu}-$ azurin. (b) Space filling models of the residues comprising the holehopping pathway from $\mathrm{Cu}$ to $\mathrm{RuHis}^{107}$.

provides an even larger distribution of arrangements for productive hopping, which will be the case as long as the driving force for the first step is not more favorable than that for overall transfer.

We tested these predictions experimentally in three $\mathrm{Ru}-$ His-labeled azurins using nitrotyrosinate $\left(\mathrm{NO}_{2} \mathrm{TyrO}^{-}\right)$ as a redox intermediate $\left(\mathrm{RuHis}^{107}\left(\mathrm{NO}_{2} \mathrm{TyrOH}\right)^{109}\right.$; $\mathrm{RuHis}^{124}\left(\mathrm{NO}_{2} \mathrm{TyrOH}\right)^{122}$; and RuHis ${ }^{126-}\left(\mathrm{NO}_{2} \mathrm{TyrOH}\right)^{122}$; $E^{\circ}\left(\mathrm{NO}_{2} \mathrm{TyrO}^{\circ /-}\right) \approx 1.02 \mathrm{~V}$ versus $\mathrm{NHE}$ ) (Fig. 2) (Warren et al. 2013a). The first two systems have cofactor placements that are close to the predicted optimum; the last system has a larger first-step distance, which is predicted to decrease the hopping advantage. The phenol $\mathrm{p} K_{\mathrm{a}}$ of 3-nitrotyrosine (7.2) permitted us to work at near-neutral $\mathrm{pH}$, rather than high $\mathrm{pH}(>10)$ required for hopping with tyrosinate. ET via nitrotyrosinate avoids the complexities associated with the proton-coupled redox reactions of tyrosine. We found specific rates of $\mathrm{Cu}^{\mathrm{I}}$ oxidation more than 10 times greater than those of single-step ET in the corresponding azurins lacking $\mathrm{NO}_{2}$ TyrOH, confirming that $\mathrm{NO}_{2} \mathrm{TyrO}^{-}$accelerates long-range ET. The results are in excellent agreement with hopping maps developed using semiclassical ET theory and parameters derived from our body of protein ET measurements (Gray \& Winkler, 2010; Warren et al. 2012, 2013a).

\section{Potential radical transfer pathways in iron oxygenases}

The cytochromes P450 are members of a superfamily of heme oxygenases that perform two broad functional roles: xenobiotic metabolism and biosynthesis (Denisov et al.
2005; Johnson \& Stout, 2013; Nebert et al. 2013; Orr et al. 2012; Whitehouse et al. 2012). The oxygenation chemistry catalyzed by some P450 enzymes is tightly coupled to substrate hydroxylation: one mole of product is produced for each mole of $\mathrm{O}_{2}$ consumed. In many enzymes, however, particularly the eukaryotic proteins with broad substrate specificities, hydroxylation is much less efficiently coupled to $\mathrm{O}_{2}$ consumption (frequently less than 10\%) (Denisov et al. 2007a; Grinkova et al. 2013; Staudt et al. 1974). When the enzyme does not transfer an $\mathrm{O}$-atom to substrate, it can produce $\mathrm{ROS}\left(\mathrm{O}_{2}^{-}, \mathrm{H}_{2} \mathrm{O}_{2}\right)$ or a second $\mathrm{H}_{2} \mathrm{O}$ molecule (Puntarulo \& Cederbaum, 1998). The production of ROS can lead to rapid degradation of the enzyme and other harmful chemistry. In the case of oxidase chemistry (formation of $2 \mathrm{H}_{2} \mathrm{O}$ from $\mathrm{O}_{2}$ ), two reducing equivalents must be delivered by sources other than the substrate. When a CYP enzyme binds a refractory substrate, ferryl formation is likely to proceed, but substrate hydroxylation is inhibited. Under these circumstances, chains of redox-active Tyr, Trp, Cys, and/or Met residues can direct the oxidizing hole to the protein periphery where it can react with intracellular antioxidants such as glutathione.

Enzymes from the 2OG-Fe superfamily use 2-oxoglutarate as a 2-electron donating co-substrate, $\mathrm{Fe}^{2+}$ as a cofactor, and $\mathrm{O}_{2}$ to effect the hydroxylation of organic substrates (Fig. 1). The 2OG-Fe enzymes exhibit a wide array of biological functions including collagen biosynthesis, lysyl hydroxylation of RNA splicing proteins, DNA repair, RNA modification, chromatin regulation, epidermal growth factor-like domain modification, hypoxia sensing, and fatty acid metabolism (Mantri et al. 2012; Rose et al. 2011). The 2OG-Fe oxygenase enzymes have conserved double-stranded $\beta$-helix folds with octahedral Fe-binding sites with the HXD/E...H triad providing two His imidazole ligands and one monodentate carboxylate ligand. The remaining three coordination sites in the resting enzyme are occupied by $\mathrm{O}$-donors from $2 \mathrm{OG}$ and a water ligand.

Several 2OG-Fe enzymes have been reported to undergo autocatalyzed oxidative modifications of aromatic amino acids. In the taurine-2OG dioxygenase that catalyzes the conversion of taurine to bisulfite, EPR data indicate the transient formation of a $\mathrm{Tyr}^{73}$-based radical that converts to an $\mathrm{Fe}^{\mathrm{III}}$-catecholate (Mantri et al. 2012). In 2,4-dichlorophenoxyacetate oxygenase (TfdA) and factorinhibiting hypoxia-inducible factor (FIH) there is evidence for Trp hydroxylation when substrate is unavailable (Mantri et al. 2012). These aromatic amino acid oxidations lead to inactivation of the enzyme. As with P450, we suggest that radical chains of Trp, Tyr, Cys, and/or Met residues in 2OG-Fe hydroxylases protect the enzymes from damage in the event of slow or unsuccessful substrate hydroxylation by diverting the powerfully oxidizing hole from $\mathrm{Fe}^{\mathrm{IV}}(\mathrm{O})$ to the protein surface, where it can react with intracellular reductants (e.g. glutathione). This diversion of oxidizing 
equivalents would extend the functional lifetime of an enzyme.

When considering the many remarkable transformations catalyzed by natural enzymes, it is easy to be left with the impression that these macromolecules are perfect catalysts that, after millions of years of tinkering, have solved the riddle of simultaneously maximizing speed, selectivity, and specificity. Upon closer inspection, however, heme and nonheme oxygenases are far from perfect catalysts, yet manage to accomplish their primary functions. Indeed, in many oxygenases, the coupling between oxygen consumption and substrate hydroxylation is extremely low. The most abundant P450 in human liver, CYP3A4, is a case in point (Denisov et al. 2007b; Grinkova et al. 2013). For enzyme incorporated into nanodiscs (Grinkova et al. 2010), the coupling of substrate hydroxylation to NADH consumption was $\leq 16 \%$ for testosterone as a substrate, $\leq 10 \%$ for bromocriptine, and 2\% for tamoxifen (Grinkova et al. 2013). It is fair to say that, although the primary CYP3A4 function may be substrate hydroxylation, the primary enzyme activity is distributed more or less equally between $\mathrm{H}_{2} \mathrm{O}_{2}$ and $\mathrm{H}_{2} \mathrm{O}$ production (Grinkova et al. 2013). Indeed, it would not be inaccurate to characterize CYP3A4 as a flawed oxidase that occasionally oxygenates organic substrates. More importantly, unless the enzyme was protected from damage in the event of uncoupled turnover, CYP3A4 would function not as a catalyst but as a stoichiometric reagent. A similar situation exists for uncoupled turnover in the 2OG-Fe enzymes.

The active sites of heme and nonheme oxygenases often are deeply buried within a polypeptide matrix. Consequently, powerfully oxidizing active site holes cannot efficiently migrate in single-step tunneling reactions to the enzyme surface for reduction by external reagents (Winkler \& Gray, $2014 a, b$ ). We have shown that multistep tunneling reactions can be hundreds to thousands of times faster than their single-step counterparts (Shih et al. 2008; Warren et al. 2012, 2013a, b). Radical transfer pathways composed of Tyr, Trp, Cys, and Met residues are ideally suited to deliver active-site oxygenase holes to enzyme surfaces when reaction with substrate is disrupted.

A biologically useful Fe-oxygenase protection mechanism requires that a fine balance be struck between substrate reaction and hole migration to the surface. Overly efficient hole migration would lower enzyme hydroxylation activity, while a sluggish pathway would be ineffective at protecting the enzyme. Active-site hole scavenging in P450 by the natural reductase may be possible, but the timing of this reaction would be extremely variable, owing to fluctuations in reductase concentration. In the 2OG-Fe enzymes, there is no reductase that could protect the enzyme. An intraprotein radical transfer mechanism can be tuned to provide the proper balance between enzyme protection and substrate reaction. We suggest that the first step in the hole-migration pathway is the critical determinant of ferryl survival time. Once a radical forms on the first residue in the pathway (the gateway residue), further migration to the surface is rapid. In the potential pathways that we have identified, the distance from the active site to the first pathway residue is often longer than subsequent steps. In addition to the longer distance, proton coupling and enzyme conformational changes could contribute to limiting the rate of the first step in the transfer chain.

\section{CYP102A1}

CYP102A1 from Bacillus megaterium (also known as P450 $\mathrm{BM} 3$ ) is a rare example of a bacterial Class II cytochrome P450 enzyme in which both reductase and heme domains are contained within a single polypeptide chain (Miura \& Fulco, 1974; Narhi \& Fulco, 1986). The enzyme catalyzes the remarkably rapid hydroxylation of long-chain fatty acids using $\mathrm{NAD}(\mathrm{P}) \mathrm{H}$ and $\mathrm{O}_{2}$, without the presence of any other proteins or cofactors (Narhi \& Fulco, 1986). The full-length enzyme $\left(\mathrm{CYP} 102 \mathrm{~A} 1_{\mathrm{HR}}\right)$ has been expressed in Escherichia coli, as have independent heme (CYP102A1 $\left.1_{\mathrm{H}}\right)$ and reductase $\left(\mathrm{CYP} 102 \mathrm{~A} 1_{\mathrm{R}}\right)$ domains (Boddupalli et al. 1990, 1992; Li et al. 1991a; Narhi et al. 1988; Oster et al. 1991). The individual domains, as well as an assembly between the heme domain and a flavin-containing reductase domain, have been structurally characterized (Girvan et al. 2007; Sevrioukova et al. 2000; Warman et al. 2005). The soluble, $119 \mathrm{kDa}$ CYP102A1 $1_{\mathrm{H}}$ enzyme serves as a convenient model system for the more complex membrane-bound enzyme assemblies (Whitehouse et al. 2012).

Uncoupled substrate, $\mathrm{O}_{2}$, and $\mathrm{NAD}(\mathrm{P}) \mathrm{H}$ consumption in $\mathrm{P} 450$ catalysis is a well-recognized and relatively common phenomenon (De Matteis et al. 2002, 2012; Denisov et al. 2007a; Grinkova et al. 2013; Puntarulo \& Cederbaum, 1998; Staudt et al. 1974). If two reducing equivalents are not delivered to $\mathrm{O}_{2}$ by the substrate, then alternative sources are necessary to avoid ROS production and/or enzyme degradation. In some cases, the extra equivalents can be delivered by $\mathrm{NAD}(\mathrm{P}) \mathrm{H}$, leading to $\mathrm{NAD}(\mathrm{P}) \mathrm{H}: \mathrm{O}_{2}$ molar consumption ratios greater than 1 (De Matteis et al. 2012). Exogenous reductants such as bilirubin and uroporphyrinogen have been shown to contribute reducing equivalents during $\mathrm{NAD}(\mathrm{P}) \mathrm{H} / \mathrm{O}_{2} \mathrm{CYP} 102 \mathrm{Al}$ turnover in the presence of halogenated (perfluorolaurate) substrates (De Matteis et al. 2012). Although it is possible that an active site hole could tunnel to the protein surface in a single step, a multistep radical transfer mechanism would be far more efficient. There are two attractive radical transfer pathways from the CYP102A1 heme to the protein surface (Fig. 3) (Girvan et al. 2007). Pathway I is comprised of heme-Trp ${ }^{96}-\operatorname{Trp}^{90}-\mathrm{Tyr}^{334}$; pathway II is heme-Cys ${ }^{156}-$ $\mathrm{Tyr}^{115}-\mathrm{Met}^{112}-\mathrm{Tyr}^{305}$. 


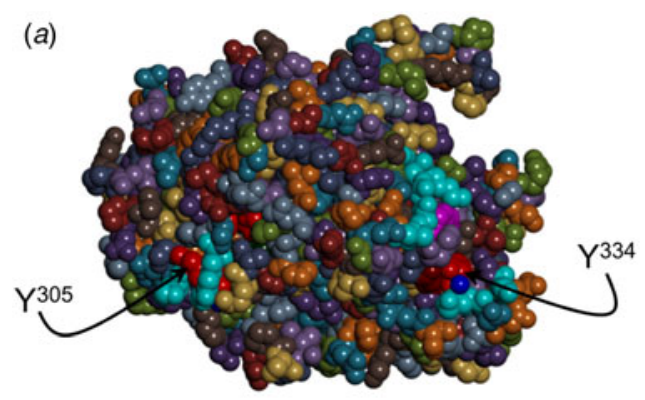

(b)

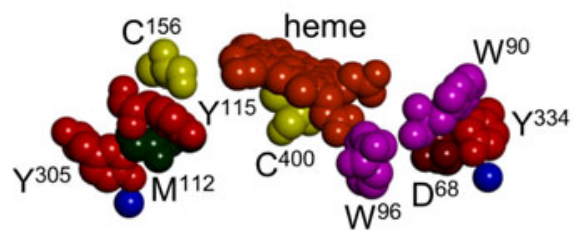

Fig. 3. (a) Space-filling structural model of the heme domain of CYP102A1 (PDB \#2IJ2) highlighting the surface locations of terminal residues in pathways I $\left(\mathrm{Tyr}^{334}\right)$ and II $\left(\mathrm{Tyr}^{305}\right)$. (b) Space-filling model of the residues comprising CYP102A1 radical transfer pathways I and II. Blue spheres represent structurally resolved water molecules.

\section{CYP102A1 radical transfer pathway I}

The shortest direct distance between aromatic atoms of CYP102A1 $\operatorname{Trp}^{96}$ and the heme is $7.3 \AA$ and $\operatorname{Trp}(\mathrm{N} \varepsilon)^{96}$ is hydrogen bonded to the heme propionate (Girvan et al. 2007). Sequence alignment (UniProtKB) in the P450 family suggests that Trp is conserved at this position in $>75 \%$ of the members of this group. Interestingly, of the 698 sequences with Trp at this position, all but 5 derive from eukaryotic sources, whereas about half of the proteins with His at this position derive from bacterial or archaeal sources. In this regard, it is noteworthy that archaeal CYP119 does not have a Trp residue at this site and is the only P450 in which Cmpd-1 has been characterized (Park et al. 2002; Rittle \& Green, 2010). The strong conservation of the $\operatorname{Trp}^{96}$ residue has been noted previously (Munro et al. 1994). To the best of our knowledge, no role other than structural has been reported for this highly conserved Trp residue in P450 (Whitehouse et al. 2012).

We suggest that $\operatorname{Trp}^{96}$ is the gateway residue for hole transfer from the heme to the protein surface during uncoupled turnover. Studies of the reactions of substrate-free $\mathrm{P} 450_{\text {cam }}$ (CYP101) with peracids revealed that a second intermediate (Cmpd-ES) forms as a result of ET from a Tyr residue to Cmpd-1 (Schünemann et al. 2004; Spolitak et al. 2005, 2006, 2008). A Cmpd-ES intermediate has been detected in CYP102A1 and $\operatorname{Trp}^{96}$ has been implicated as one of the residues hosting the oxidized radical (Raner et al. 2006). Addition of NADPH to Cmpd-ES of the CYP102 $2_{\mathrm{HR}}$ holoenzyme regenerates the ferric resting state; and formation of these radicals may play a protective role during uncoupled P450 catalysis (Spolitak et al. 2006). A combined computational/experimental investigation of CYP102A1 implicated

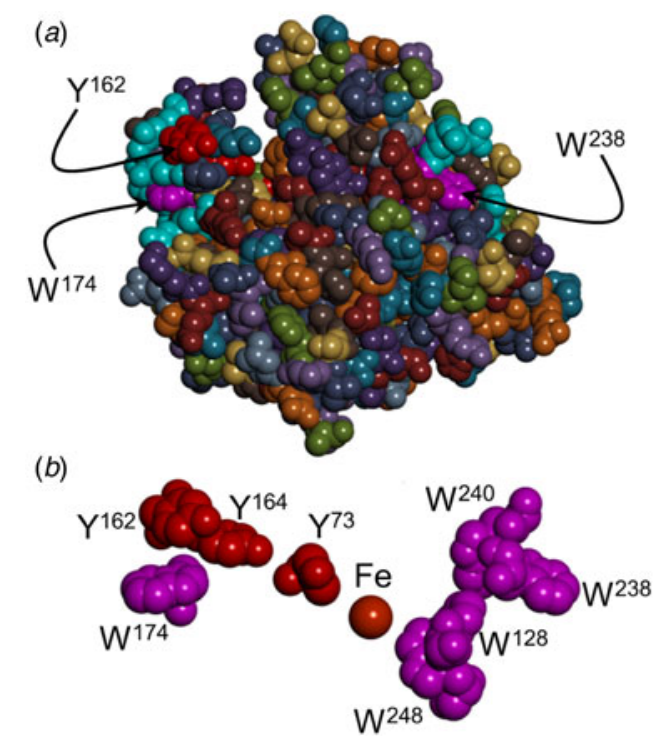

Fig. 4. (a) Space-filling structural model of E. coli TauD (PDB \#1OS7) highlighting the surface locations of terminal residues in postulated radical transfer pathways $\left(\operatorname{Trp}^{238}, \operatorname{Trp}^{174}\right.$, and $\operatorname{Tyr}^{162}$ ). (b) Space-filling model of the residues comprising TauD radical transfer pathways.

buried $\operatorname{Trp}^{96}, \operatorname{Trp}^{90}, \mathrm{His}^{92}$, and $\mathrm{Tyr}^{334}$ residues as components of an ET pathway that could deliver reducing equivalents to Cmpd-1 from the protein surface (Vidal-Limon et al. 2013). The shortest aromatic contacts in this chain are: $\operatorname{Trp}^{96}-\operatorname{Trp}^{90}, 8.4 \AA$; $\operatorname{Trp}^{90}-\mathrm{Tyr}^{334}, 4.4 \AA$ (Girvan et al. 2007). The environment around $\mathrm{Tyr}^{334}$ appears well-suited for radical formation: the phenol hydroxyl group is hydrogen-bonded to both a carboxylate $\left(\mathrm{Asp}^{68}\right)$ and a water molecule $\left(\mathrm{HOH}^{1215}\right)$.

Our prior studies of P450 ET reactions are consistent with involvement of $\operatorname{Trp}^{96}$ in a radical transfer pathway to the heme (Ener et al. 2010). We have found that $\mathrm{Ru}^{\mathrm{II}}(\mathrm{bpy})_{2}\left(\right.$ phen $\left.^{-}-\mathrm{Cys}^{97}\right)$ can deliver an electron across $24 \AA$ to the $\mathrm{Fe}^{\mathrm{III}}$-heme in $20 \mu \mathrm{s}$, and $\mathrm{Ru}^{\mathrm{III}}$ (bpy) $)_{2}$ (phen$\left.\mathrm{Cys}^{97}\right) \mathrm{CYP} 102 \mathrm{~A} 1_{\mathrm{H}}$ can oxidize the heme to a porphyrin radical in under $2 \mu$ s (Ener et al. 2010). The latter reaction is particularly rapid given the low driving force $(<200$ $\mathrm{meV}$ ) expected for the transformation. We have prepared a $\operatorname{Trp}^{96} \mathrm{His}$ mutant and found that $\mathrm{Ru}^{\mathrm{III}}(\mathrm{bpy})_{2}$ (phen$\left.\mathrm{Cys}^{97}\right)\left(\mathrm{His}^{96}\right) \mathrm{CYP} 102 \mathrm{Al}_{\mathrm{H}}$ does not promote photochemical heme oxidation to Cmpd-2. Electron transfer to the $\mathrm{Fe}^{\mathrm{III}}$-heme from $\mathrm{Ru}^{\mathrm{II}}(\text { bpy })_{2}\left(\right.$ phen $\left.^{-}-\mathrm{Cys}^{97}\right)\left(\mathrm{His}^{96}\right)$, however, is unaffected by the $\operatorname{Trp}^{96} \mathrm{His}$ mutation.

\section{CYP102A1 radical transfer pathway II}

The second potential radical transfer pathway in CYP102A1, heme-Cys ${ }^{156}-\mathrm{Tyr}^{115}-\mathrm{Met}^{112}-\mathrm{Tyr}^{305}$, does not appear as favorable as pathway I, due largely to a long distance between the heme and the first step in the path. The distance from $\mathrm{Cys}(\mathrm{S} \gamma)^{156}$ to the closest heme aromatic 


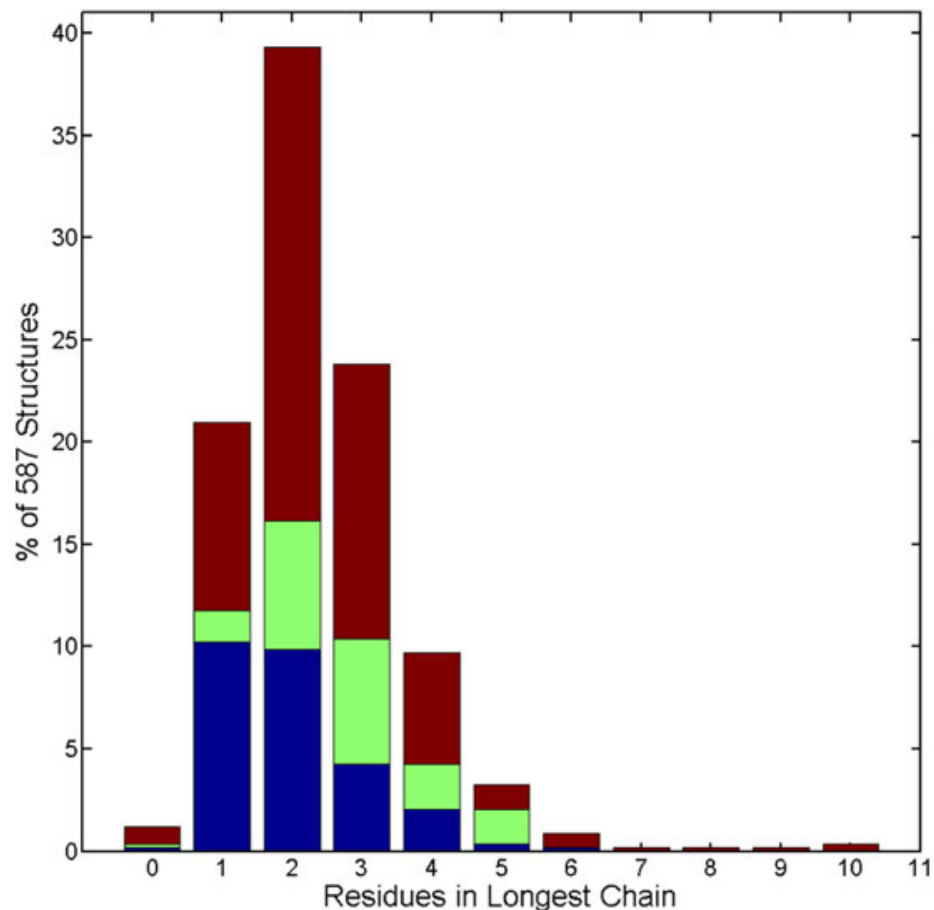

Fig. 5. Distributions of radical transfer chain lengths among structurally characterized oxidoreductases from enzyme sub-classes EC 1.11 (peroxidases, blue), 1.13 (oxygenases, green), and 1.14 (dioxygenases, red). Radical transfer chains are defined to be composed of Tyr, Trp, heme, Fe, and $\mathrm{Cu}$ residues. Tyr residues were included only if a carboxylate (Asp, Glu) oxygen atom, an imidazole (His) nitrogen atom, or a water molecule was within $4 \AA$ of the Tyr hydroxyl oxygen atom.

carbon atom (10.8 $\AA$ ) is slightly longer than the shortest aromatic-aromatic contact between the heme and $\mathrm{Tyr}^{115}$ (10.2 $\AA$ ). If a radical is formed on $\mathrm{Tyr}^{115}$, then hole transport to the surface $\operatorname{Tyr}^{305}$ via $\operatorname{Met}(\mathrm{S} \delta)^{112}$ could provide a secondary protection route.

\section{Potential radical transfer pathways in 20G-Fe oxygenases}

TauD

The 2-oxoglutarate nonheme iron oxygenases catalyze substrate hydroxylation reactions in a fashion that is reminiscent of the cytochromes P450, but with some critical distinctions (Fig. 1). The consensus mechanism for catalysis involves $\mathrm{Fe}^{2+}$ binding to the apo-enzyme followed by $2 \mathrm{OG}$ incorporation. Substrate binding induces loss of the water ligand from $\mathrm{Fe}^{2+}$, creating a vacant coordination site for $\mathrm{O}_{2}$ binding. Oxidation of $2 \mathrm{OG}$ produces $\mathrm{CO}_{2}$, succinate, and an $\mathrm{Fe}^{\mathrm{IV}}(\mathrm{O})$ center that is thought to hydroxylate substrate via the usual $\mathrm{H}$-atom abstraction, hydroxyl rebound cycle (Mantri et al. 2012; Rose et al. 2011). The 2OG-Fe hydroxylases differ from the $\mathrm{P} 450$ enzymes in that substrate hydroxylation proceeds from the $\mathrm{Fe}^{\mathrm{IV}}(\mathrm{O})$ oxidation level (equivalent to P450 Cmpd-2). The E. coli 2OG-Fe enzyme TauD is synthesized under conditions of sulfur deprivation (Hausinger, 2004); large quantities of TauD have been prepared by over expression in E. coli BL21(DE3) (pME4141) cells (Eichhorn et al. 1997; Ryle et al. 1999). The enzyme catalyzes the hydroxylation of taurine (2-aminoethanesulfonate), producing an unstable species that decomposes into sulfite and aminoacetaldehyde (Hausinger, 2004). In the absence of taurine, the enzyme will slowly consume $\mathrm{O}_{2}$ and become inactivated: protein analysis indicates hydroxylation of $\mathrm{Tyr}^{73}$ (Koehntop et al. 2006; Ryle et al. 2003). Although with deuterated substrates coupling between oxygen consumption and substrate hydroxylation is diminished, $2 \mathrm{OG}$ oxidation is not, suggesting that $\mathrm{Fe}^{\mathrm{IV}}(\mathrm{O})$ continues to be formed in the presence of refractory substrates; and bis-Tris buffer, a potential reducing agent, decreases coupling between $\mathrm{O}_{2}$ activation and $\mathrm{C}-\mathrm{H}$ hydroxylation (McCusker \& Klinman, 2009). We suggest that when $\mathrm{Fe}^{\mathrm{IV}}(\mathrm{O})$ is unable to effect substrate hydroxylation, the oxidizing hole is directed to the protein surface where it can be reduced by external reagents.

\section{TauD radical transfer pathways}

We have identified two possible radical transfer pathways in the structure of TauD: the most attractive pathway from $\mathrm{Fe}$ to the surface has four Trp residues: $\mathrm{Fe}-\operatorname{Trp}^{248}-\operatorname{Trp}^{128}$ $\operatorname{Trp}^{240}-\operatorname{Trp}^{238}$; relevant distances are: $\mathrm{Fe}-\operatorname{Trp}^{248}, 4.8 \AA$; $\operatorname{Trp}^{248}-\operatorname{Trp}^{128}, 3.1 \AA ; \operatorname{Trp}^{128}-\operatorname{Trp}^{240}, 3.7 \AA ; \operatorname{Trp}^{240}-\operatorname{Trp}^{238}$, $3.7 \AA$ (Fig. 4) (O’Brien et al. 2003). The structure of this 
Trp chain compares favorably to that identified in E. coli DNA photolyase (4-5 ̊ separations) (Byrdin et al. 2003; Lukacs et al. 2006). The photolyase chain has just three Trp residues, and hole migration from $\mathrm{FADH}^{*}$ to $\operatorname{Trp}^{306}$ at the protein surface is complete in less than $10 \mathrm{~ns}$ (Byrdin et al. 2003; Lukacs et al. 2006). We anticipate that a hole injected by $\mathrm{Fe}^{\mathrm{IV}}(\mathrm{O})$-TauD into $\operatorname{Trp}^{248}$ should migrate to $\operatorname{Trp}^{238}$ at the surface in less than $1 \mu \mathrm{s}$. A secondary radical transfer pathway in TauD $\left[\mathrm{Fe}-\mathrm{Tyr}^{73}-\mathrm{Tyr}^{164}-\left(\operatorname{Trp}^{174}\right.\right.$, $\left.\mathrm{Tyr}^{162}\right)$ ] is of particular interest because hydroxylated $\mathrm{Tyr}^{73}$ has been found during turnover in the absence of taurine (Koehntop et al. 2006; Ryle et al. 2003). Both $\operatorname{Trp}^{174}$ and $\mathrm{Tyr}^{162}$ are well-exposed at the enzyme surface and both (or just one) of these residues could be involved in a radical transfer pathway. Relevant distances are: $\mathrm{Fe}-\mathrm{Tyr}^{73}, \quad 6.5 \AA$; $\quad \mathrm{Tyr}^{73}-\mathrm{Tyr}^{164}, \quad 5.0 \AA$ 的 $\quad \mathrm{Tyr}^{164}-\mathrm{Trp}^{174}$, $4.2 \AA$; Tyr ${ }^{164}-\mathrm{Tyr}^{162}, 7.6 \AA$; Trp ${ }^{174}-\mathrm{Tyr}^{162}, 8.8 \AA$ (O'Brien et al. 2003).

\section{Outlook}

Functional radical transfer pathways have been identified in several enzymes, including ribonucleotide reductase (Argirevic et al. 2012; Holder et al. 2012; Offenbacher et al. 2013a, b; Sjöberg, 1997; Stubbe \& van der Donk, 1998; Stubbe et al. 2003; Worsdorfer et al. 2013; Yokoyama et al. 2011), photosystem II (Boussac et al. 2013; Keough et al. 2013; Sjoholm et al. 2012), DNA photolyase (Aubert et al. 1999, 2000; Byrdin et al. 2003; Kodali et al. 2009; Li et al. 1991b; Lukacs et al. 2006; Sancar, 2003; Taylor, 1994; Woiczikowski et al. 2011), and MauG (Davidson \& Liu, 2012; Davidson \& Wilmot, 2013; Geng et al. 2013; Yukl et al. 2013). If radical transfer pathways do indeed provide protection mechanisms for enzymes operating at high electrochemical potentials, then it is likely that they will be found in many more redox-active enzymes. A survey of oxidoreductases in the protein data bank reveals that nearly $80 \%$ of structurally characterized peroxidases, oxygenases, and dioxygenases (enzyme classes EC 1.11, 1.13 , and 1.14; 587 structures with sequence identity less than $90 \%$ ) contain chains of 2 or more redox-active residues (Tyr, Trp, heme, Fe, and $\mathrm{Cu}$ ) separated by no more than $5 \AA$ (Fig. 5). The fraction increases to almost $90 \%$ if the cutoff distance is increased to $8 \AA$. We think it very likely that hole hopping through these types of radical transfer chains greatly reduces the production of ROS that destroy enzymes and other molecules in living cells.

\section{Acknowledgments}

We thank Maraia Ener, Jeff Warren, Lionel Cheruzel, Kana Takematsu, and Oliver Shafaat for helpful discussions.

\section{Financial support}

Research reported in this publication was supported by The National Institute of Diabetes and Digestive and Kidney Diseases of the National Institutes of Health under award number R01DK019038 to HBG and JRW. The content is solely the responsibility of the authors and does not necessarily represent the official views of the National Institutes of Health. Additional support was provided by the Arnold and Mabel Beckman Foundation.

\section{References}

Argirevic, T., Riplinger, C., Stubbe, J., Neese, F. \& Bennati, M. (2012). ENDOR spectroscopy and DFT calculations: evidence for the hydrogen-bond network within alpha 2 in the PCET of E. coli ribonucleotide reductase. Journal of the American Chemical Society 134, 17661-17670.

Aubert, C., Mathis, P., Eker, A. P. M. \& Brettel, K. (1999). Intraprotein electron transfer between tyrosine and tryptophan in DNA photolysase from Anacystis nidulans. Proceedings of the National Academy of Sciences of the United States of America 96, 5423-5427.

Aubert, C., Vos, M. H., Mathis, P., Eker, A. P. M. \& Brettel, K. (2000). Intraprotein radical transfer during photoactivation of DNA photolyase. Nature 405, 586-590.

Blanco-Rodriguez, A. M., Di Bilio, A. J., Shih, C., Museth, A. K., Clark, I. P., Towrie, M., Cannizzo, A., Sudhamsu, J., Crane, B. R., Sykora, J., Winkler, J. R., Gray, H. B., Zalis, S. \& Vlcek, A. (2011). Phototriggering electron flow through $\mathrm{Re}^{\mathrm{I}}$-modified Pseudomonas aeruginosa azurins. Chemistry - A European Journal 17, 5350-5361.

Boddupalli, S. S., Estabrook, R. W. \& Peterson, J. A. (1990). Fatty-acid monooxygenation by cytochrome-P-450BM-3. Journal of Biological Chemistry 265, 4233-4239.

Boddupalli, S. S., Oster, T., Estabrook, R.W. \& Peterson, J.A. (1992). Reconstitution of the fatty-acid hydroxylation function of cytochrome-P-450BM-3 utilizing its individual recombinant hemoprotein and flavoprotein domains. Journal of Biological Chemistry 267, 10375-10380.

Bonin, J., Costentin, C., Louault, C., Robert, M., Routier, M. \& Saveant, J. M. (2010). Intrinsic reactivity and driving force dependence in concerted proton-electron transfers to water illustrated by phenol oxidation. Proceedings of the National Academy of Sciences of the United States of America 107, 3367-3372.

Boussac, A., Rappaport, F., Brettel, K. \& Sugiura, M. (2013). Charge recombination in $\mathrm{S}_{\mathrm{n}} \mathrm{Tyr}_{\mathrm{Z}} \mathrm{Q}_{\mathrm{A}}^{-}$radical pairs in D1 protein variants of photosystem II: long range electron transfer in the marcus inverted region. Journal of Physical Chemistry B 117, 3308-3314.

Byrdin, M., Eker, A.P. M., Vos, M. H. \& Brettel, K. (2003). Dissection of the triple tryptophan electron transfer chain in Escherichia coli DNA photolyase: Trp382 is the primary donor in photoactivation. Proceedings of the National Academy of Sciences of the United States of America 100, 8676-8681.

Chen, Y. H., Comeaux, L. M., Herbst, R. W., Saban, E., Kennedy, D. C., Maroney, M. J. \& Knapp, M. J. (2008). Coordination changes and auto-hydroxylation of FIH-1: uncoupled $\mathrm{O}_{2}$-activation in a 
human hypoxia sensor. Journal of Inorganic Biochemistry 102, 2120-2129.

Costentin, C., Louault, C., Robert, M. \& Saveant, J. M. (2009). The electrochemical approach to concerted proton-electron transfers in the oxidation of phenols in water. Proceedings of the National Academy of Sciences of the United States of America 106, 18143-18148.

DAVIDSON, V. L. \& LiU, A. M. (2012). Tryptophan tryptophylquinone biosynthesis: a radical approach to posttranslational modification. Biochimica et Biophysica Acta - Proteins and Proteomics 1824, 1299-1305.

DaVIDSON, V. L. \& Wilmot, C. M. (2013). Posttranslational biosynthesis of the protein-derived cofactor tryptophan tryptophylquinone. Annual Review of Biochemistry 82, 531-550.

De Matteis, F., Ballou, D. P., Coon, M. J., Еsтabrook, R. W. \& Haines, D. C. (2012). Peroxidase-like activity of uncoupled cytochrome P450. Studies with bilirubin and toxicological implications of uncoupling. Biochemical Pharmacology 84, 374-382.

De Matteis, F., Dawson, S. J., Pons, N. \& Pipino, S. (2002). Bilirubin and uroporphyrinogen oxidation by induced cytochrome P4501A and cytochrome P4502B - role of polyhalogenated biphenyls of different configuration. Biochemical Pharmacology 63, 615-624.

Denisov, I. G., BaAs, B. J., Grinkova, Y. V. \& Sligar, S. G. (2007a). Cooperativity in cytochrome P450 3A4 - Linkages in substrate binding, spin state, uncoupling, and product formation. Journal of Biological Chemistry 282, 7066-7076.

Denisov, I. G., Grinkova, Y.V., McLean, M.A. \& Sligar, S.G. (2007b). The one-electron autoxidation of human cytochrome p450 3A4. Journal of Biological Chemistry 282, 26865-26873.

Denisov, I. G., Makris, T. M., Sligar, S. G. \& Schlichting, I. (2005). Structure and chemistry of cytochrome P450. Chemical Reviews 105, 2253-2277.

Eichhorn, E., van der Ploeg, J. R., Kertesz, M. A. \& Leisinger, T. (1997). Characterization of $\alpha$-Ketoglutarate-dependent taurine dioxygenase from Escherichia coli. Journal of Biological Chemistry 272, 23031-23036.

Ener, M. E., Lee, Y. T., Winkler, J. R., Gray, H. B. \& Cheruzel, L. (2010). Photooxidation of cytochrome P450-BM3. Proceedings of the National Academy of Sciences of the United States of America 107, 18783-18786.

Farver, O. \& Pecht, I. (2011). Electron transfer in blue copper proteins. Coordination Chemistry Reviews 255, 757-773.

Geng, J.F., Dornevil, K., Davidson, V.L. \& Liu, A. M. (2013). Tryptophan-mediated charge-resonance stabilization in the bis-Fe(IV) redox state of MauG. Proceedings of the National Academy of Sciences of the United States of America 110, 9639-9644.

Girvan, H. M., Seward, H. E., Toogood, H. S., Cheesman, M. R., Leys, D. \& Munro, A.W. (2007). Structural and spectroscopic characterization of P450BM3 mutants with unprecedented P450 heme iron ligand sets - new heme ligation states influence conformational equilibria in P450BM3. Journal of Biological Chemistry 282, 564-572.

GraY, H. B. \& WinkLeR, J. R. (2010). Electron flow through metalloproteins. Biochimica Et Biophysica Acta - Bioenergetics 1797, 1563-1572.

Grinkova, Y. V., Denisov, I. G., McLean, M.A. \& Sligar, S.G. (2013). Oxidase uncoupling in heme monooxygenases: human cytochrome P450 CYP3A4 in nanodiscs. Biochemical and Biophysical Research Communications 430, 1223-1227.

Grinkova, Y. V., Denisov, I. G. \& Suigar, S. G. (2010). Functional reconstitution of monomeric CYP3A4 with multiple cytochrome P450 reductase molecules in nanodiscs. Biochemical and Biophysical Research Communications 398, 194-198.

Harriman, A. (1987). Further comments on the redox potentials of tryptophan and tyrosine. Journal of Physical Chemistry 91, 61026104.

HAUSINGER, R. P. (2004). Fe(II)/alpha-ketoglutarate-dependent hydroxylases and related enzymes. Critical Reviews in Biochemistry and Molecular Biology 39, 21-68.

Holder, P. G., Pizano, A. A., Anderson, B. L., Stubbe, J. \& Nocera, D. G. (2012). Deciphering radical transport in the large subunit of class I ribonucleotide reductase. Journal of the American Chemical Society 134, 1172-1180.

Johnson, E. F. \& Stout, C. D. (2013). Structural diversity of eukaryotic membrane cytochrome P450s. Journal of Biological Chemistry 288, 17082-17090.

Jovanic, S. V., Harriman, A. \& Simic, M. G. (1986). Electrontransfer reactions of tryptophan and tyrosine derivatives. Journal of Physical Chemistry 90, 1935-1939.

Keough, J. M., Zuniga, A. N., Jenson, D. L. \& Barry, B. A. (2013). Redox control and hydrogen bonding networks: proton-coupled electron transfer reactions and tyrosine $\mathrm{Z}$ in the photosynthetic oxygen-evolving complex. Journal of Physical Chemistry B 117, 1296-1307.

Kodali, G., Siddiqui, S. U. \& Stanley, R. J. (2009). Charge redistribution in oxidized and semiquinone E. coli DNA photolyase upon photoexcitation: stark spectroscopy reveals a rationale for the position of Trp382. Journal of the American Chemical Society 131, 4795-4807.

Koehntop, K. D., MarimanikKuppam, S., Ryle, M. J., HausingeR, R. P. \& QuE, L. (2006). Self-hydroxylation of taurine/alpha-ketoglutarate dioxygenase: evidence for more than one oxygen activation mechanism. Journal of Biological Inorganic Chemistry 11, 63-72.

Li, H. Y., Darwish, K. \& Poulos, T. L. (1991a). Characterization of recombinant Bacillus megaterium cytochrome-P-450BM-3 and its 2 functional domains. Journal of Biological Chemistry 266, 11909-11914.

LI, Y. F., Heelis, P. F. \& SANCAR, A. (1991b). Active site of DNA photolyase: tryptophan-306 is the intrinsic hydrogen atom donor essential for flavin radical photoreduction and DNA repair in vitro. Biochemistry 30, 6322-6329.

Lukacs, A., Eker, A. P. M., Byrdin, M., Villette, S., Pan, J., Brettel, K. \& Vos, M. H. (2006). Role of the middle residue in the triple tryptophan electron transfer chain of DNA photolyase: ultrafast spectroscopy of a Trp $\rightarrow$ Phe mutant. Journal of Physical Chemistry B 110, 15654-15658.

Mantri, M., Zhang, Z.H., McDonough, M. A. \& Schofield, C. J. (2012). Autocatalysed oxidative modifications to 2-oxoglutarate dependent oxygenases. FEBS Journal 279, 1563-1575.

Marcus, R. A. \& Sutin, N. (1985). Electron transfers in chemistry and biology. Biochimica et Biophysica Acta 811, 265-322.

MCCuskeR, K. P. \& KuINMAN, J. P. (2009). Modular behavior of tauD provides insight into the origin of specificity in alphaketoglutarate-dependent nonheme iron oxygenases. Proceedings of the National Academy of Sciences of the United States of America 106, 19791-19795. 
Miura, Y. \& Fulco, A. J. (1974). (Omega - 2) Hydroxylation of fatty-acids by a soluble system from Bacillus megaterium. Journal of Biological Chemistry 249, 1880-1888.

Munro, A. W., Malarkey, K., McKnight, J., Thomson, A. J., Kelly, S. M., Price, N. C., Lindsay, J. G., Coggins, J.R. \& Miles, J. S. (1994). The role of tryptophan-97 of cytochrome-P450-BM3 from Bacillus megaterium in catalytic function - evidence against the covalent-switching hypothesis of P450 electron-transfer. Biochemical Journal 303, 423-428.

NARHI, L. O. \& FulCO, A. J. (1986). Characterization of a catalytically self-sufficient 119,000-dalton cytochrome-P-450 monooxygenase induced by barbiturates in Bacillus megaterium. Journal of Biological Chemistry 261, 7160-7169.

Narhi, L. O., Wen, L. P. \& Fulco, A. J. (1988). Characterization of the protein expressed in Escherichia coli by a recombinant plasmid containing the Bacillus megaterium cytochrome-P-450BM-3 gene. Molecular and Cellular Biochemistry 79, 63-71.

Nebert, D. W., Wikvall, K. \& Miller, W. L. (2013). Human cytochromes $\mathrm{P} 450$ in health and disease. Philosophical Transactions of the Royal Society B - Biological Sciences 368 (1612), 20120431.

O’Brien, J. R., Schuller, D. J., Yang, V. S., Dillard, B. D. \& LANZILOTTA, W. N. (2003). Substrate-induced conformational changes in Escherichia coli taurine/ $\alpha$-ketoglutarate dioxygenase and insight into the oligomeric structure. Biochemistry 42, 5547-5554.

Offenbacher, A.R., Burns, L. A., Sherrill, C.D. \& Barry, B. A. (2013a). Redox-linked conformational control of proton-coupled electron transfer: Y122 in the ribonucleotide reductase $\beta 2$ subunit. Journal of Physical Chemistry B 117, 8457-8468.

Offenbacher, A. R., Minnihan, E. C., Stubbe, J. \& Barry, B. A. (2013b). Redox-linked changes to the hydrogen-bonding network of ribonucleotide reductase $\beta 2$. Journal of the American Chemical Society 135, 6380-6383.

OrR, S. T. M., Ripp, S. L., Ballard, T. E., Henderson, J. L., Scott, D. O., Овach, R.S., Sun, H. \& KalgutKar, A.S. (2012). Mechanism-based inactivation (MBI) of cytochrome P450 enzymes: structure-activity relationships and discovery strategies to mitigate drug-drug interaction risks. Journal of Medicinal Chemistry 55, 4896-4933.

Oster, T., Boddupalli, S. S. \& Peterson, J.A. (1991). Expression, purification, and properties of the flavoprotein domain of cytochrome-P-450BM-3 - evidence for the importance of the amino-terminal region for FMN binding. Journal of Biological Chemistry 266, 22718-22725.

Park, S.-Y., Yamane, K., Adachi, S.-I., Shiro, Y., Weiss, K. E., Maves, S.A. \& Sligar, S. G. (2002). Thermophilic cytochrome P450 (CYP119) from Sulfolobus solfataricus: high resolution structure and functional properties. Journal of Inorganic Biochemistry 91, 491-501.

Puntarulo, S. \& Cederbaum, A. I. (1998). Production of reactive oxygen species by microsomes enriched in specific human cytochrome P450 enzymes. Free Radical Biology and Medicine 24, 1324-1330.

Raner, G. M., Thompson, J. I., Haddy, A., Tangham, V., Bynum, N., Reddy, G. R., Ballou, D.P. \& Dawson, J.H. (2006). Spectroscopic investigations of intermediates in the reaction of cytochrome P450(BM3)-F87G with surrogate oxygen atom donors. Journal of Inorganic Biochemistry 100, 2045-2053.
Reece, S. Y. \& Nocera, D. G. (2009). Proton-coupled electron transfer in biology: results from synergistic studies in natural and model systems. Annual Review of Biochemistry, 78, 673-699.

Rittle, J. \& Green, M. T. (2010). Cytochrome P450 compound I: capture, characterization, and $\mathrm{C}-\mathrm{H}$ bond activation kinetics. Science 330, 933-937.

Rose, N. R., McDonough, M. A., King, O. N. F., Kawamura, A. \& SCHofield, C. J. (2011). Inhibition of 2-oxoglutarate dependent oxygenases. Chemical Society Reviews 40, 4364-4397.

Ryle, M. J., Liu, A., Muthukumaran, R. B., Ho, R. Y. N., Koehntop, K. D., McCracken, J., Que, L. \& Hausinger, R. P. (2003). O-2and alpha-ketoglutarate-dependent tyrosyl radical formation in TauD, an alpha-keto acid-dependent non-heme iron dioxygenase. Biochemistry 42, 1854-1862.

Ryle, M. J., Padmakumar, R. \& Hausinger, R. P. (1999). Stopped-flow kinetic analysis of Escherichia coli taurine/ $\alpha$-ketoglutarate dioxygenase: interactions with $\alpha$-ketoglutarate, taurine, and oxygen $\dagger$. Biochemistry 38, 15278-15286.

Saban, E., FlagG, S.C. \& KnapP, M. J. (2011). Uncoupled $\mathrm{O}_{2}$-activation in the human HIF-asparaginyl hydroxylase, $\mathrm{FIH}$, does not produce reactive oxygen species. Journal of Inorganic Biochemistry 105, 630-636.

SANCAR, A. (2003). Structure and function of DNA photolyase and cryptochrome blue-light photoreceptors. Chemical Reviews 103, 2203-2238.

Schưnemann, V., Lendzian, F., Jung, C., Contzen, J., Barra, A. L., Sligar, S. G. \& Trautwein, A. X. (2004). Tyrosine radical formation in the reaction of wild type and mutant cytochrome P450cam with peroxy acids - a multifrequency EPR study of intermediates on the millisecond time scale. Journal of Biological Chemistry 279, 10919-10930.

Sevrioukova, I. F., Immoos, C. E., Poulos, T. L. \& Farmer, P. (2000). Electron transfer in the ruthenated heme domain of cytochrome P450BM-3. Israel Journal of Chemistry 40, 47-53.

Shim, C., Museth, A. K., Abrahamsson, M., Blanco-Rodriguez, A. M., Di Bilio, A. J., Sudhamsu, J., Crane, B. R., Ronayne, K. L., Towrie, M., Vlcek, A., Richards, J.H., Winkler, J.R. \& Gray, H.B. (2008). Tryptophan-accelerated electron flow through proteins. Science 320, 1760-1762.

SJöBERG, B. M. (1997). Ribonucleotide reductases - a group of enzymes with different metallosites and a similar mechanism. Structure and Bonding 88, 139-173.

Sjoholm, J., Styring, S., Havelius, K. G. V. \& Ho, F. M. (2012). Visible light induction of an electron paramagnetic resonance split signal in photosystem II in the S-2 state reveals the importance of charges in the oxygen-evolving center during catalysis: a unifying model. Biochemistry 51, 2054-2064.

Spolitak, T., Dawson, J. H. \& Ballou, D. P. (2005). Reaction of ferric cytochrome P450cam with peracids - kinetic characterization of intermediates on the reaction pathway. Journal of Biological Chemistry 280, 20300-20309.

Spolitak, T., Dawson, J. H. \& Ballou, D. P. (2006). Rapid kinetics investigations of peracid oxidation of ferric cytochrome P450cam: nature and possible function of compound ES. Journal of Inorganic Biochemistry 100, 2034-2044.

Spolitak, T., Dawson, J. H. \& Ballou, D. P. (2008). Replacement of tyrosine residues by phenylalanine in cytochrome $\mathrm{P} 450 \mathrm{cam}$ alters the formation of Cpd II-like species in reactions with artificial oxidants. Journal of Biological Inorganic Chemistry 13, 599-611. 
Staudt, H., Lichtenk, F. \& Ullrich, V. (1974). Role of NADH in uncoupled microsomal monoxygenations. European Journal of Biochemistry 46, 99-106.

Stubbe, J., Nocera, D. G., Yee, C.S. \& Chang, M. C. Y. (2003). Radical initiation in the class I ribonucleotide reductase: long-range proton-coupled electron transfer? Chemical Reviews 103, 2167-2201.

Stubbe, J. \& van der Donk, W. A. (1998). Protein radicals in enzyme catalysis. Chemical Reviews 98, 705-762.

Takematsu, K., Williamson, H., Blanco-Rodríguez, A. M., Sokolová, L., Nikolovski, P., Kaiser, J. T., Towrie, M., Clark, I. P., VlČeK, A., WinkleR, J. R. \& GraY, H. B. (2013). Tryptophan-accelerated electron flow across a protein-protein interface. Journal of the American Chemical Society 134, 15515-15525.

TAYLOR, J.S. (1994). Unraveling the molecular pathway from sunlight to skin cancer. Accounts of Chemical Research 27, 76-82.

Vidal-Limon, A., Aguila, S., Ayala, M., Batista, C. V. \& Vazquez-Duhalt, R. (2013). Peroxidase activity stabilization of cytochrome P450(BM3) by rational analysis of intramolecular electron transfer. Journal of Inorganic Biochemistry 122, $18-26$.

Warman, A. J., Roitel, O., Neeli, R., Girvan, H. M., Seward, H. E., Murray, S. A., McLean, K. J., Joyce, M. G., Toogood, H., Holt, R. A., Leys, D., Scrutton, N. S. \& Munro, A. W. (2005). Flavocytochrome P450BM3: an update on structure and mechanism of a biotechnologically important enzyme. Biochemical Society Transactions 33, 747-753.

Warren, J. J., Ener, M. E., VlČeK, A., Winkler, J. R. \& Gray, H. B. (2012). Electron hopping through proteins. Coordination Chemistry Reviews 256, 2478-2487.

Warren, J. J., Herrera, N., Hill, M. G., Winkler, J. R. \& Gray, H. B. (2013a). Electron flow through nitrotyrosinate in Pseudomonas aeruginosa azurin. Journal of the American Chemical Society 135, 11151-11158.

Warren, J. J., Winkler, J. R. \& Gray, H. B. (2013b). Hopping maps for photosynthetic reaction centers. Coordination Chemistry Reviews 257, 165-170.

Whitehouse, C. J. C., Bell, S. G. \& Wong, L. L. (2012). P450BM3 (CYP102A1): connecting the dots. Chemical Society Reviews 41, 1218-1260.
WiKSTRÖM, M. (2012). Active site intermediates in the reduction of $\mathrm{O}_{2}$ by cytochrome oxidase, and their derivatives. Biochimica et Biophysica Acta - Bioenergetics 1817, 468-475.

WiLson, T. D., YU, Y. \& Lu, Y. (2013). Understanding copperthiolate containing electron transfer centers by incorporation of unnatural amino acids and the $\mathrm{Cu}-\mathrm{A}$ center into the type 1 copper protein azurin. Coordination Chemistry Reviews 257, 260-276.

WinkLer, J. R. \& GraY, H. B. (2014a). Electron flow through metalloproteins. Chemical Reviews 114, 3369-3380.

WinkLER, J. R. \& GRAY, H. B. (2014b). Long-range electron tunneling. Journal of the American Chemical Society 136, 2930-2939.

Woiczikowski, P. B., Steinbrecher, T., Kubař, T. \& Elstner, M. (2011). Nonadiabatic QM/MM simulations of fast charge transfer in Escherichia coli DNA photolyase. Journal of Physical Chemistry B 115, 9846-9863.

Worsdorfer, B., Conner, D. A., Yokoyama, K., Livada, J., Seyedsayamdost, M., Jiang, W., Silakov, A., Stubbe, J., Bollinger, J. M. \& Krebs, C. (2013). Function of the Diiron Cluster of Escherichia coli class Ia ribonucleotide reductase in proton-coupled electron transfer. Journal of the American Chemical Society 135, 8585-8593.

Yokoyama, K., Smith, A. A., Corzilius, B., Griffin, R. G. \& Stubbe, J. (2011). Equilibration of tyrosyl radicals (Y-356, Y-731', Y-730 ) in the radical propagation pathway of the Escherichia coli class Ia ribonucleotide reductase. Journal of the American Chemical Society 133, 18420-18432.

Yu, M. A., Egawa, T., Shinzawa-Itoh, K., Yoshikawa, S., Guallar, V., Yeh, S. R., Rousseau, D. L. \& Gerfen, G. J. (2012). Two tyrosyl radicals stabilize high oxidation states in cytochrome $c$ oxidase for efficient energy conservation and proton translocation. Journal of the American Chemical Society 134, 4753-4761.

Yu, M. A., Egawa, T., Shinzawa-Itoh, K., YoshiKawa, S., Yeh, S. R., Rousseau, D. L. \& Gerfen, G. J. (2011). Radical formation in cytochrome $c$ oxidase. Biochimica et Biophysica Acta - Bioenergetics 1807, 1295-1304.

Yukl, E. T., Liu， F. G., Krzystek, J., Shin， S., Jensen, L. M. R., Davidson, V. L., Wilmot, C. M. \& LiU, A. M. (2013). Diradical intermediate within the context of tryptophan tryptophylquinone biosynthesis. Proceedings of the National Academy of Sciences of the United States of America 110, 4569-4573. 